\title{
Corporate tax savings when hiring a Big 4 auditor: Empirical evidence for Belgium
}

\author{
B. Janssen, H. Vandenbussche, K. Crabbé \\ Catholic University of Leuven
}

March 2005

\begin{abstract}
In this paper we show that hiring a Big 4 auditor results in substantial corporate income tax savings, compared to hiring a non-Big 4 auditor. Our results are obtained from an empirical model that controls for other factors that may affect companies' income tax burdens. We use a population of larger Belgian firms between 1993 and 2002. The findings suggest that Big 4 audited firms provide (explicitly or implicitly) additional tax expertise which is transferred to their clients and lowers their effective tax rates compared to non-Big 4 audited firms.
\end{abstract}

Keywords: Belgian firms, Big 4 Auditor, Effective Tax Rates, financial statements

Address for correspondence: Boudewijn Janssen, Faculty of Law, Universiteit Maastricht, P.O.Box 616, 6200 MD Maastricht, The Netherlands, T: + 3143388 3202, Email: boudewijn.janssen@belastr.unimaas.nl

We thank the Research Council of the Catholic University of Leuven for funding this research. We thank Willem Buijink, Staf van Herck, Heidi Vander Bauwhede, Ann Vanstraelen and Marleen Willekens for comments. 


\section{Introduction}

In July 2002, the US introduced the Sarbanes-Oxley Act as a result of recent company debacles. One of the features of this act is the mandatory separation of audit and non-audit services. Shortly after this date, in August 2002, the Belgian Parliament passed the "Corporate Governance law" which has a number of features similar to the Sarbanes-Oxley Act. Perhaps the most important aspect of the Belgian law is a better definition of auditor independence and a clear outline of what constitutes violations of independence. These regulations make it now impossible for Belgian auditing firms to provide both audit services and (tax) consulting services to the same client.

However, our period of analysis is limited to the period prior to the enactment of the law. During this period both audit services and (tax) consulting services could be provided to the same client. Actually, providing both types of services at the same time was common practice in Belgium (Vander Bauwhede and Willekens, 2004). Because audit fees and audit service quality are directly monitored by the Belgian institute of auditors, it is difficult for Belgian auditors to compete by means of audit fees or audit service quality levels ${ }^{1}$. One of the few options for Belgian audit firms to compete in the period under investigation is by transferring knowledge from audit services to non-audit services, especially tax planning services. Because incentives to transfer information between (competing) auditing firms are limited, it is more advantageous to contract both audit and tax services from one audit firm. As indicated above, this is not allowed anymore. Belgian firms are obliged to report their auditor firm(s), but not their tax consultant, in their annual statements. Because of the intertwined nature of audit services and tax consulting services and the close link in Belgium between financial statements and tax statements in the period of our analysis 1993-2002, the Big 4 auditor variable can be regarded as a proxy for receiving explicit or implicit tax consulting services.

The results in this paper suggest that firms with a Big 4 auditor have a lower Effective Tax Rate $^{2}$ than firms with a non Big 4 auditor. Our interpretation of this result is that firms hiring a

\footnotetext{
${ }^{1}$ Vander Bauwhede and Willekens (2004) document the absence of a relationship between auditor size and audit service quality.

${ }^{2}$ The effective tax rate proxies for the actual tax burden paid by companies, as the actual tax burden is not widely
} 
Big 4 auditor either implicitly or explicitly had access to better quality tax expertise that lowered their Effective Tax Rate compared to other firms. By providing better quality tax planning services, embedded in audit services, Big 4 audit firms are able to offset their higher audit fees with lower effective tax rates for their clients.

Our analysis uses firm level data that control for a number of firm-level factors, apart from the size of the auditor, which may affect the Effective Tax Rate (ETR). While the statutory tax rate in the period of our analysis did not change at $40.17 \%$, we find a large heterogeneity between firms in terms of the Effective Tax Rate reported ${ }^{3}$. Our analysis indicates that while statutory tax incentives explain some of the variation in ETRs, a large part of the variation can be attributed to other factors, such as the size of a firm, the type of corporate finance used and the type of auditor it employs, the latter being the focus of this study. Sector membership also turns out to be an important factor in explaining the heterogeneity in ETRs.

Although the STR did not change in the period we analyze, we do observe yearly increases in average ETRs in the 1990s, as discussed in Vandenbussche, Janssen and Crabbé (2004). This can be related to changes in statutory tax rates ${ }^{4}$ and/or tax bases ${ }^{5}$.

Our results indicate that hiring a Big 4 auditor results (on average) for the firms in our sample in a 1 to $2 \%$ points decrease in the Effective Tax Rate, depending on the specification of the model. Given that the average Effective Tax Rate we observe for the sample as a whole equals $26 \%$ and the average reported earnings before tax are 1,284,632 Euro, the tax savings generated by hiring a Big 4 auditor range between about 13,000 and 26,000 Euro on average. These results also hold when performing different robustness checks.

Our results can provide the missing link in current research on Belgian audit fees. Willekens

available in Belgian financial statements.

${ }^{3}$ A few other studies have analyzed (European) firm level ETRs using different data sets such as Buijink, Janssen and Schols (2002) and Huizinga and Nicodème (2003).

${ }^{4}$ Belgium recently lowered its STR from $40.17 \%$ to $33.9 \%$ from the year 2003 onwards. Many other EU countries have also lowered their STR. For example the STR of Italy was reduced from 52.20\% in 1993 to $40.25 \%$ in 2002. For Denmark the STR decreased from 36\% in 1993 to 30\% in 2002 (KPMG (2003)).

${ }^{5}$ Devereux, Griffith and Klemm (2002) find that tax rate-cutting and base-broadening reforms usually go hand in hand leaving the effective tax rates fairly stable over time. 
and Achmadi (2003) were able, on the basis of a random sample of Belgian firms, to determine that the average audit fee in the private client market in 1989 was about 495,000 Belgian Francs (about 12,276 Euro). They also found that Big 4 audit firm charge higher audit fees. On the other hand, Vander Bauwhede and Willekens (2004) find no relationship between auditor size and audit service quality. In essence this means that Big 4 audit firms charge an audit fee premium, while not delivering a better audit service quality. Our findings indicate that audit fee premiums for Big 4 audit firms are justified because Big 4 audit firms provide their clients not only with audit services, but also with implicit tax advice ${ }^{6}$. This results in lower effective tax rates for Big 4 audited firms.

The remainder of this paper is structured as follows: the next two sections give an overview of relevant literature regarding statutory and accounting aspects of Belgian corporate taxation. The collection and analysis of the data is discussed in Section 4. Section 5 provides some descriptive statistics with section 6 introducing the empirical model, whereas section 7 provides a discussion of the main results. Section 8 contains some robustness checks, while the last section concludes and summarizes the main results.

\section{Previous Research}

An important line of academic research has focused on the association between auditor characteristics (e.g., audit quality ${ }^{7}$ ) and measures of earnings quality or earnings management (e.g., Balsam, Krishnan, and Yang, 2003, Becker, Defond, Jiambalvo, and Subramanyam, 1998, Krishnan, 2003). This research has often found that higher levels of auditor quality are associated with lower levels of earnings management. These studies were all performed on listed firms, often in a USA context. Vander Bauwhede and Willekens (2004) who also analyze Belgian data find for the private client market that a Big 4 auditor does not provide a quality premium and does not affect earnings management compared to non Big 4 auditors. They interpret this as the result of a lower demand for high quality auditing services because

\footnotetext{
${ }^{6}$ Audit firms may also provide explicit tax advice, potentially also resulting in lower effective tax rates. Due to data considerations we are not able to analyze the impact of explicit tax advice.

${ }^{7}$ Audit quality is often proxied by Big 4 auditor expertise or auditor industry specialization.
} 
of lower levels of information asymmetry between the owners and the managers of a firm. Another possible explanation for this finding is the controlled nature of the audit market in Belgium. Information on both audit fees and audit service quality levels has to be reported to the Belgian institute of auditors. In contrast, similar information on (tax) consulting services does not have to be provided. The Big Four ${ }^{8}$ auditors are the largest auditing firms, consisting of Deloitte, Ernst \& Young, KPMG and PriceWaterhouseCoopers. This research has, typically, not investigated the effect on net income of hiring a Big Four auditor, but has rather focused on the levels of discretionary accruals (Lennox, 1999).

Auditors not only provide audit services, but also, in the Belgian context, tax services. Some research has investigated tax function activities at firms. Dunbar and Philips (2001) investigate why firms outsource tax planning and tax compliance functions. They find that such decisions are affected by, among others, transaction costs relating to human-asset specificity. They also find that firms with more of a tax-planning focus, outsource greater (lesser) proportions of their tax-planning (-compliance) activities (Dunbar and Philips, 2001, p. 35). Mills, Erickson and Maydew (1998) investigate the associations between company characteristics and tax related expenditures. Among others, they find that relative tax planning costs decrease in firm size.

To measure actual corporate tax burdens, different measures are available. According to Nicodème (2001), the best measure to capture the actual average tax burden on corporate income, is the average ETR measure. This measure expresses the corporate income tax expense relative to pre-tax financial accounting income and has widely been used in tax related research (see, for example, Callihan, 1994 and Shackelford and Shevlin, 2001). The absolute ETR levels or the differences between ETR levels and statutory tax rates indicate to what extent firms are able to reduce taxes payable by means of tax planning/tax compliance strategies. The degree in which tax and audit services are interrelated depends on the (statutory) context of the audit market.

\footnotetext{
${ }^{8}$ Prior to a number of mergers, these firms were also knows as Big Five, Big Six, Big Seven and Big Eight auditing firms. All of the previous auditing firms included in this list were coded as a Big 4 auditing firm.
} 


\section{Statutory Framework}

In this section we explain the determinants of the statutory tax base and the statutory tax incentives that applied in our period of investigation 1993-2002. Also, a number of specific aspects relating to the audit profession are mentioned. The corporate income tax system in Belgium has a stepwise progressive tax rate system with rates ranging from $28 \%$ up to $40.17 \%{ }^{9}$ In Belgium tax statements and financial statements are closely linked. This is a result of Belgium being a country using the "continental" model (Roberts, Weetman and Gordon, 2002, p. 113). In a "continental" model there is a close relationship between the financial statements and the tax statements. While the relationship in Belgium is not one where both types of statements are identical, differences between the two types of statements are very limited. This is in contrast to countries using a "business" oriented model, such as the USA and the UK (Roberts, Weetman and Gordon, 2002, p. 113). These countries have an (almost) complete lack of relationship between the financial statements and tax statements. This means that in a "continental" model, such as in Belgium, the reporting of financial figures in financial statements has often direct repercussions for the amount of taxes owed to the government. This implies that auditors can almost directly influence the taxable income when changing financial accounting income. Auditors with additional expertise (e.g., Big 4 auditors) can therefore provide implicit tax advice to their clients when auditing the financial statements. That is, there is a spillover effect from auditing financial statements towards tax statements. Because of their expertise, Big 4 auditors should be able to provide more and/or higher quality implicit tax advice.

While we do not observe the true tax base ${ }^{10}$ in our data, we do observe the yearly reported income/profits by each firm, which is used by the tax authorities to determine the tax base, in the following manner. First, from the annual income/profit figures that firms report, the tax authority can reject a number of expenses, which are not deemed to be true expenses of the period. This would enlarge the tax base. Secondly, firms can get a tax facility for dividends

\footnotetext{
${ }^{9}$ All the firms in our sample have reported income/profits over 89,500 $€$ which makes the highest STR their relevant marginal tax rate. Based on the actual income levels and relevant tax brackets, the weighted average STR is $39.88 \%$, which is very close to the top marginal tax rate of $40.17 \%$ which we will use throughout the text.

${ }^{10}$ The true tax base is generally not reported in Belgian financial statements.
} 
received from affiliated firms to avoid double taxation of dividend income. ${ }^{11}$ Thirdly, there is a tax facility for losses reported in the past ('carry-forwards'). ${ }^{12}$ And finally, tax incentives are also granted for four types of investments: investments in patents, investments in Research $\&$ Development, investments in energy-saving technology and other investments ${ }^{13}$. The extent to which expenses are rejected by the tax authority, as well as some of the statutory or negotiated tax incentives a company enjoys can not be observed in our data. However, we do know the total 'tax expenses' a firm owes to the tax authority. A widely used manner to measure ETRs is by relating the firm level 'income taxes expense" ${ }^{14}$ to the "reported profits before tax' (Callihan, 1994, Shackelford and Shevlin, 2001, Buijink, Janssen and Schols, 2002). The extent to which the ETR differs from the STR is indicative of how the tax base relates to the reported profits before taxes in our financial statements data. If the ETR is below the STR, which on average is the case, the tax base is smaller than the reported earnings and the firm enjoys tax incentives.

\section{Data}

We use a rich panel dataset of 12,197 larger Belgian firms ${ }^{15}$ over a period of 10 years covering 1993-2002. Our final sample contains 95,768 firm-year observations ${ }^{16}$. The dataset was obtained from the commercial database BELFIRST which contains the financial

\footnotetext{
${ }^{11}$ When dividends come from associated firms, $95 \%$ of the dividend revenue is free of Belgian corporate tax. For affiliates within the European Union (participation $>25 \%$ ) a full exemption is granted.

${ }^{12}$ The taxable income may be reduced with losses of previous periods. In Belgium losses can only be deducted from future profits, this is called carry-forward of losses (Vankerckhove and Heirewegh (2003)).

${ }^{13}$ For the period we analyse (1993-2002), the tax facility for each of these investments was $13.5 \%$ of the cost of investment except for other investments with a rate of $3.5 \%$

${ }^{14}$ The "income tax expense" includes both current and deferred income taxes, whereas the "reported profits before tax" are the financial accounting income before taxes, both as reported in the income statement.

${ }^{15}$ The firms in this sample represent $21 \%$ of Belgian employment.

${ }^{16}$ Based on the sample of 12,197 firms for 10 years, 121,970 firm-year observations were possible. However, only 109,347 firm-year observations were actually available. After removal of extreme observations, the panel has 95,768 firm-year observations. the 13,579 extreme observations included 10,167 negative ETR observations and 3,412 observations with an ETR larger than 1. The 95,769 firm-year observations include 617 firm-year observations from listed firms.
} 
statements of all incorporated Belgian firms. We excluded very small firms ${ }^{17}$ as these only have to provide condensed financial statements, not containing all of the variables required for our analysis. We excluded financial institutions like banks and insurance companies, because they are subject to different accounting rules and reporting standards. Our analysis is based on unconsolidated financial statements ${ }^{18}$ and we only consider ETR observations between 0 and 1 to control for outliers as in Collins and Shackelford (2002). While the BELFIRST dataset contains data for the years 1989 to 2002, the availability varies between years. Especially, the availability of data for the years 1989-1992 is very limited. Therefore, the focus of our analysis is on the period 1993-2002.

\section{Descriptive Statistics}

The (average) ETR is referred to as a micro backward-looking measure of corporate tax pressure (Devereux, Griffith and Klemm, 2002). This variable is our dependent variable in the regression analysis in the next section ${ }^{19}$. Table 1 presents descriptive statistics (mean, median and standard deviation) for the overall ETR and separately for Big 4, non Big 4 audited firms and firms with missing data. A first observation is that while the average ETR for large Belgian firms is around 26\%, the median ETR is higher and lies around $29 \%$. The higher value for the median, which captures the middle observation, suggests that the ETR distribution is skewed to the left caused by a number of companies with low ETRs. A study by Buijink, Janssen and Schols (2002) finds an average ETR for Belgium of 21.64\%, but for a significantly smaller dataset of only 350 firm-year observations. Their dataset consists of observations for the largest Belgian firms only. This might indicate that these very large companies are effectively taxed at lower rates than the firms in our data sample. Second,

\footnotetext{
${ }^{17}$ Very small firms are defined according to the European Union fourth company law directive. When a firm fulfills at least two of the following three criteria it is a small firm: balance sheet total of less than $€ 3.125$ million, net turnover of less than $€ 6.25$ million and less than 50 employees.

${ }^{18}$ In Belgium there is no fiscal consolidation, hence the unconsolidated accounts are used to determine tax expenses.

${ }^{19}$ To the extent that the independent variables are correlated amongst themselves, multicollinearity may be a problem. Collinearity diagnostics do not indicate such a problem. Vandenbussche, Janssen and Crabbé (2005) provide specific information on the relationship between company characteristics and ETR levels.
} 
although all large Belgian firms are subject to the same statutory tax rate, the standard deviations in Table 1 indicate a lot of firm heterogeneity in ETRs. Third, mean and median ETRs of Big 4 and non Big 4 audited firms differ clearly, while the mean and median ETR of Big 4 audited firms are clearly below the mean and median ETR of non Big 4 audited firms. This indicates that Big 4 audited firms have a more right skewed distribution compared to non Big 4 audited firms.

Table 1: Average Effective Tax Rates

\begin{tabular}{|l|l|l|l|l|}
\hline ETR1 & Belgium & Big 4 audited & Non Big 4 audited & Missing data \\
\hline Mean & 0.2615 & 0.2414 & 0.2795 & 0.2414 \\
median & 0.2917 & 0.2129 & 0.3390 & 0.1351 \\
std. dev. & 0.2464 & 0.2447 & 0.2442 & 0.2637 \\
$\mathrm{~N}^{\circ}$ observations & 95,768 & 39,016 & 50,554 & 6,198 \\
\hline
\end{tabular}

In terms of the auditor data that we have, most firms report the name of the auditing firm that certified the accounts. In our data about $18.9 \%$ of the firms report a Big 4 auditor, while $71.99 \%$ report a non-Big Four auditor. This confirms the finding by De Beelde (1997) that the Belgian market structure of the audit market consists of many small auditing firms and a few large ones.

\section{Model and Variable Definitions}

The empirical model we introduce in this section closely follows the literature (e.g., Huizinga and Nicodème, 2003 and Buijink, Janssen and Schols, 2000) by including firm characteristics and sector dummies to explain firm level ETRs. In addition to the approach used in this line of literature we also include year dummies, proxies for statutory tax incentives and a dummy capturing the type of auditor used by the firm in a particular year, where we distinguish between Big 4 auditors and non-Big 4 auditors. Definitions for the different variables are included in appendix Table A2, whereas the correlation matrix is listed in appendix Table A1. The empirical specification of the multivariate model we test has the following general form: 
where the dependent variable, ETR, is the effective tax rate of firm $\mathrm{i}$ in year $\mathrm{t}$, for one of the years between 1993-2002.

An important firm characteristic variable in previous ETR research has been FIRM SIZE, which has predominantly been measured by the log of total assets but this has resulted in ambiguous signs as argued by Gupta and Newberry (1997). For this reason we also proxy firm size by the log of total employment at the firm level (EMPLOYM). The correlation between both firm size proxies is about 0.65 , indicating that both proxies are partially complementary to each other ${ }^{20}$.

We also include a set of variables proxying for a number of statutory tax breaks (LEGAL), such as capital intensity (Cap), long term leverage (Ltleverage) and R\&D expenses (R\&Dintens). Specific tax rules allow for additional deductions, as well as for specific depreciation rules. The capital intensity of a company is defined as the ratio of fixed tangible assets over total assets. This variable can affect ETR through the tax treatment of depreciation $^{21}$ or through the tax breaks for investments. ${ }^{22}$ Long-term leverage is defined as the ratio of long-term debt over total assets. One reason for including this variable is that interest payments on debt are fully deductible as long as the creditor is a financial company institution (Vankerckhove and Heirewegh (2003)). As discussed above, there is also a tax facility for R\&D investments and patents. This is the main reason for including the R\&Dintens variable which is defined as the ratio of intangible fixed assets over total assets. ${ }^{23}$ A specific statutory tax break is available for so called coordination centers. A dummy variable is included to control for this facility, being 1 when the firm is classified as a coordination center. ${ }^{24}$ For these statutory tax break variables we expect a negative effect on ETR. The variable BIG 4 is a dummy variable with a value of 1 when the firm is audited by one of the Big 4 auditing firms in a particular year and a value of 0 if not.

To analyze the yearly evolution of ETRs over the period we include 9 year dummies (y1994-

\footnotetext{
${ }^{20}$ Due to multicollinearity problems, no interaction variable FIRMSIZE*BIG4 is included in the model.

${ }^{21}$ Depreciation is an expense of the period and lowers the tax base.

${ }^{22}$ For energy saving investments the company can deduct $13.5 \%$ of the purchase value of the investment from the taxable income (Vankerckhove and Heirewegh (2003)).

${ }^{23}$ We have also experimented with including the AGE of a firm, but this variable never turned out to be significant and was therefore dropped from the analysis.

${ }^{24}$ Co-ordination centers are part of a multinational group and engage in financial or business services for this group. They have to pay less taxes in Belgium.
} 
y2002) with 1993 as the reference year. Finally, to control for sector heterogeneity we include 33 sector dummies at the two-digit Nace-Bel level. We also include an error term $\left(\varepsilon_{i t}\right)$ to control for white noise. In the next section we report the results of an Ordinary Least squares (OLS) regression where we take into account that firm observations in consecutive years are not independent observations. For this reason we cluster around firm observations using a unique identifier for each firm. We also use normal standard errors to control for heteroscedasticity.

\section{Empirical Results}

In this section we discuss our main results. Table 2 reports the main OLS regression results for model (1), using all available observations for the period 1993-2002. In column (1) we use the logarithm of total assets as size variable, while column (2) uses the log of employment as a proxy for firm size.

Both firm size variables have a small positive effect on the ETR, indicating that larger firms pay higher taxes. This result has also been found in other studies like Gupta and Newberry (1997) and Zimmerman (1983) for the US. However, the size effect is also dependent on the specification of the empirical model as discussed in Vandenbussche, Janssen and Crabbé (2004).

All the 'LEGAL' variables come with the expected sign, lowering ETRs. So, highly leveraged firms with many interest expenses have lower ETRs, as well as firms that invest in R\&D. Capital intensive firms have lower ETRs as a result of higher depreciation.

The results in Table 2 also confirm that co-ordination centers have a lower ETR. The BIG 4 auditor dummy is negative and significant both in columns (1) and (2), suggesting that having a BIG 4-auditor 'pays off' by lowering the Effective Tax Rate ${ }^{25}$ a firm faces, even in a multivariate setting controlling for other factors possibly influencing ETRs. ${ }^{26}$ However, the

${ }^{25}$ Mills and Newberry (2001) specify book-tax income differences as dependent variable instead of ETR. Taxable income data are not directly available in our dataset, can, however be estimated by dividing the tax expense by the STR. Usage of this estimated book-tax income difference variable provides similar results as the ETR variable.

${ }^{26}$ Some firms do not report their auditor. In our data these observations get a value of 0 for the BIG 4 auditor dummy. However, running a regression where we delete these observation rather than treating them as zeros, 
possibility arises that firms audited by BIG 4 auditors, happen to be foreign owned firms or more generally firms that belong to an international group. If that is the case, what we are picking up with the Big 4 auditor dummy may just reflect that a firm is more international which could result in lower Effective Tax rates for other reasons. To disentangle the two effects, in column (3) of Table 2, we include two control variables in addition to the BIG 4auditor dummy. One is a foreign ownership dummy (FOWN) that has a value of 1 when at least one foreign shareholder has more than or equal to $50 \%$ of the shares. The other control variable is a dummy with a value of 1 , when the Belgian firm has at least $50 \%$ of the shares in a foreign subsidiary. By including these two variables we want to make sure that the BIG 4auditor effect is truly driven by the type of auditor a firm is using and not the fact that it belongs to a group. The results in Table 2 suggest that even when including these two additional control variables the BIG 4-auditor dummy remains negative and significant in column (3), suggesting that it has explanatory value on top of international group membership.

\section{Table 2: Regression Results}

BIG 4 auditor dummy: $=1$ if firm has a BIG 4 auditor, $=0$ otherwise

\begin{tabular}{|l|l|l|l|}
\hline Dependent variable & $(1)$ & $(2)$ & $(3)$ \\
& ETR & ETR & ETR \\
\hline Ln (Assets) & $0.003^{*}$ & - & - \\
& {$[1.65]$} & & \\
\hline Ln (Employm) & - & $0.016^{* * *}$ & $0.025^{* * *}$ \\
& & {$[8.30]$} & {$[8.13]$} \\
\hline Ltleverage & $-0.006^{* * *}$ & $-0.008^{* *}$ & $-0.023^{* * *}$ \\
& {$[-2.76]$} & {$[-2.15]$} & {$[-2.80]$} \\
\hline Cap & $-0.051^{*}$ & $-0.047^{*}$ & $-0.134^{* * *}$ \\
& {$[-1.85]$} & {$[-1.66]$} & {$[-5.54]$} \\
\hline R\&Dintens & $-0.242^{* * *}$ & $-0.243^{* * *}$ & $-0.309^{* * *}$ \\
& {$[-7.55]$} & {$[-6.39]$} & {$[-5.08]$} \\
\hline Cocen & $-0.102^{* * *}$ & $-0.129^{* * *}$ & -0.092 \\
& {$[-3.28]$} & {$[-4.30]$} & {$[-1.07]$} \\
\hline BIG 4- Auditor & $-0.016^{* * *}$ & $-0.026^{* * *}$ & $-0.048^{* *}$ \\
& {$[-2.77]$} & {$[-4.28]$} & {$[-5.20]$} \\
\hline
\end{tabular}

yields the same negative and significant effect on the BIG 4 auditor dummy. 


\begin{tabular}{|c|c|c|c|}
\hline FOWN total dummy & - & - & $\begin{array}{l}-0.024^{* *} \\
{[-2.41]}\end{array}$ \\
\hline FSUBS total dummy & - & - & $\begin{array}{l}0.001 \\
{[0.13]}\end{array}$ \\
\hline Listed & - & - & - \\
\hline Year dummies & Yes & Yes & Yes \\
\hline Sector dummies & Yes & Yes & Yes \\
\hline Constant & $\begin{array}{l}0.231 * * * \\
{[8.23]}\end{array}$ & $\begin{array}{l}0.216^{* * *} \\
{[8.39]}\end{array}$ & $\begin{array}{l}0.150^{* * *} \\
{[3.97]}\end{array}$ \\
\hline Observations & 25884 & 24388 & 3600 \\
\hline $\mathrm{R}^{2}$ & 0.045 & 0.050 & 0.081 \\
\hline F-statistic & 47.62 & 24.49 & 6.53 \\
\hline Prob $>F$ & 0.000 & 0.000 & 0.000 \\
\hline
\end{tabular}

Note: $\mathrm{t}$-values are between brackets, $*=$ significance at $10 \%$ level, $* *=$ significance at $5 \%$ level, $* * *=$ significance at $1 \%$

\section{Robustness Check}

Table 3 reports some robustness checks. We start in column (1) by reporting the outcome of a dynamic specification where we include the lagged value of ETR (t-1) as an additional explanatory variable on the right hand side to control for possible autocorrelation ${ }^{27}$. However, our main variable of interest, the BIG 4 auditor dummy remains significant. In column (2) of Table 3 we report the results of a censored tobit regression that takes into account that ETR is a truncated variable. ${ }^{28}$

Another common way to control for outliers is where we cut-off all ETR observations larger or smaller than twice the standard deviation of the mean ETR. The results of this regression are shown in column (3) of Table 3. Again the results remain qualitatively the same.

In column (4) we control for carry-forwards of losses which apply under Belgian law, by including a variable (LOSS [t-1]) to capture last year's losses. Although the sign is, as expected, negative, this variable is not significant. A possible explanation is that previous year's losses is too rough as a variable, as there is no one to one relationship between losses and ETRs. Using Belgian financial statements we are unable to calculate the carry-forward

\footnotetext{
${ }^{27}$ Inclusion of previous year ETRs for several prior years is not significant in the model.

${ }^{28}$ The distribution of ETR1s is shown in Figure A.1 in the Appendix.
} 
positions of firms. Results for other variables in this robustness check are however not affected by the inclusion of the LOSS_1 variable. Overall, the robustness checks confirm the earlier findings, especially the negative effect of having a Big 4 auditor on ETR, which is significant in all examined models.

Table 3: Robustness Checks

\begin{tabular}{|c|c|c|c|c|}
\hline dependent var. & $\begin{array}{l}1) \\
\text { ETR }\end{array}$ & $\begin{array}{l}\text { (2) censored } \\
\text { ETR }\end{array}$ & $\begin{array}{l}\text { (3) } \\
2 \text { st. dev. from } \\
\text { the mean ETR }\end{array}$ & $\begin{array}{l}(4) \\
\text { ETR }\end{array}$ \\
\hline $\operatorname{ETR}(\mathrm{t}-1)$ & $\begin{array}{l}0.009 \\
{[0.99]}\end{array}$ & - & - & - \\
\hline Log of Employm & $\begin{array}{l}0.016^{* * *} \\
{[8.29]}\end{array}$ & $\begin{array}{l}0.033 * * * \\
{[20.12]}\end{array}$ & $\begin{array}{l}0.015^{* * *} \\
{[8.30]}\end{array}$ & $\begin{array}{l}0.010^{* * *} \\
{[6.11]}\end{array}$ \\
\hline Ltleverage & $\begin{array}{l}-0.008^{* *} \\
{[-2.15]}\end{array}$ & $\begin{array}{l}-0.014 * * * \\
{[-4.28]}\end{array}$ & $\begin{array}{l}-0.006^{*} \\
{[-1.89]}\end{array}$ & $\begin{array}{l}-0.004^{*} \\
{[-1.75]}\end{array}$ \\
\hline Cap intens & $\begin{array}{l}-0.047^{*} \\
{[-1.66]}\end{array}$ & $\begin{array}{l}-0.074 * * * \\
{[-11.80]}\end{array}$ & $\begin{array}{l}-0.042^{*} \\
{[-1.66]}\end{array}$ & $\begin{array}{l}-0.025 \\
{[-1.52]}\end{array}$ \\
\hline R\&Dintens & $\begin{array}{l}-0.242 * * * \\
{[-6.39]}\end{array}$ & $\begin{array}{l}-0.470 * * * \\
{[-15.14]}\end{array}$ & $\begin{array}{l}-0.277 * * * \\
{[-8.66]}\end{array}$ & $\begin{array}{l}-0.111 * * * \\
{[-3.72]}\end{array}$ \\
\hline COCEN & $\begin{array}{l}-0.129 * * * \\
{[-4.31]}\end{array}$ & $\begin{array}{l}-0.085^{* * *} \\
{[-3.28]}\end{array}$ & $\begin{array}{l}-0.122 * * * \\
{[-5.27]}\end{array}$ & $\begin{array}{l}-0.173^{* * *} \\
{[-5.72]}\end{array}$ \\
\hline Loss (t-1) & - & - & - & $\begin{array}{l}-0.244 \\
{[-64.34]}\end{array}$ \\
\hline BIG 4-Auditor & $\begin{array}{l}-0.026^{* * * *} \\
{[-4.29]}\end{array}$ & $\begin{array}{l}-0.035^{* * *} \\
{[-7.38]}\end{array}$ & $\begin{array}{l}-0.021 * * * \\
{[-3.73]}\end{array}$ & $\begin{array}{l}-0.020 * * * \\
{[-4.16]}\end{array}$ \\
\hline Year dummies & Yes & Yes & Yes & Yes \\
\hline Sector dummies & Yes & Yes & Yes & yes \\
\hline Constant & $\begin{array}{l}0.214 * * * \\
{[8.31]}\end{array}$ & $\begin{array}{l}0.088^{* * *} \\
{[4.62]}\end{array}$ & $\begin{array}{l}0.186^{* * *} \\
{[8.06]}\end{array}$ & $\begin{array}{l}0.224 * * * \\
{[10.74]}\end{array}$ \\
\hline Observations & 24388 & 24801 & 23575 & 24388 \\
\hline$\overline{\mathrm{R}^{2}}$ & 0.050 & 0.060 & 0.058 & 0.209 \\
\hline F-statistic & 23.26 & - & 27.49 & 203.33 \\
\hline
\end{tabular}

Note: t-values between brackets

$*=$ significance level at $10 \%, * *=$ significance level at $5 \%, * * *=$ significance level at $1 \%$

\section{Conclusion}

In this paper we find that firms that hire a Big4 auditor, have lower Effective tax rates than 
other firms. Our evidence is based on a data set of large Belgian firms with over 95,000 observations for the period 1993-2002.

We interpret our result of lower ETRs for firms with Big4 auditors, that these firms implicitly or explicitly obtained tax advice through their auditing firm. During the period of our analysis the Belgian law did not require a strict separation between auditing and tax services. This changed in 2002, where legal reforms were implemented demanding a strict separation between auditing services and other services provided by auditing firms. Our results seem to suggest that in the period before these reforms, the provision of auditing and tax services to the same client was common practice in Belgium.

Table A.1: Correlation Matrix

\begin{tabular}{|c|c|c|c|c|c|}
\hline & ETR1 & $\begin{array}{l}\text { Big } 4 \\
\text { auditor }\end{array}$ & ASSETS & EMPLOYMENT & LTleverage \\
\hline $\begin{array}{l}\text { BIG } 4 \\
\text { auditor }\end{array}$ & -0.043 & 1 & 0.373 & 0.299 & -0.008 \\
\hline Fown & -0.003 & 0.346 & 0.367 & 0.284 & -0.042 \\
\hline FSUBS & 0.001 & 0.096 & 0.145 & 0.081 & 0.017 \\
\hline Cocen & -0.001 & 0.044 & 0.046 & 0.044 & -0.010 \\
\hline R\&Dintens & -0.094 & 0.040 & -0.025 & -0.041 & 0.014 \\
\hline CAP & -0.117 & -0.088 & -0.071 & 0.013 & 0.131 \\
\hline LTleverage & -0.075 & -0.008 & -0.053 & -0.059 & 1 \\
\hline EMPLOYM & 0.079 & 0.299 & 0.743 & 1 & -0.059 \\
\hline ASSETS & -0.003 & 0.373 & 1 & 0.743 & -0.053 \\
\hline
\end{tabular}

\begin{tabular}{|l|l|l|l|}
\hline & CAP & R\&Dintens & Cocen \\
\hline Fown & -0.042 & -0.015 & -0.033 \\
FSUBS & -0.131 & 0.082 & 0.051 \\
\hline Cocen & -0.037 & -0.019 & 1 \\
\hline R\&Dintens & -0.111 & 1 & -0.019 \\
\hline CAP & 1 & -0.111 & -0.037 \\
\hline
\end{tabular}


Table A.2: Data-appendix

\begin{tabular}{|c|c|}
\hline ETR & Corporate Income Taxes/ Profit before Taxes \\
\hline BIG 4 Auditor & $\begin{array}{l}=1 \text { when firm is audited by one of the BIG } 4 \text { auditors; } 0 \\
\text { otherwise }\end{array}$ \\
\hline ASSETS & $\log ($ total assets) \\
\hline EMPLOYM & $\log ($ employment $)$ \\
\hline CAP & tangible fixed assets/ total assets \\
\hline LTLEVERAGE & total LT debt/ total assets \\
\hline R\&Dintens & Intangible fixed assets/ total assets \\
\hline COCEN & $=1$ if coordination centre $($ Nace-Bel $=74152),=0$ otherwise \\
\hline SECTORS & $\begin{array}{l}33 \text { sector dummies at } 2 \text { - digits Nace-Bel ( }=0 \text { if optical and } \\
\text { clocks sector) }\end{array}$ \\
\hline Y1994 - Y2002 & 9 Year dummies $(=0$ if 1993) \\
\hline
\end{tabular}

Figure A.1: Kernel Density Estimates of ETR

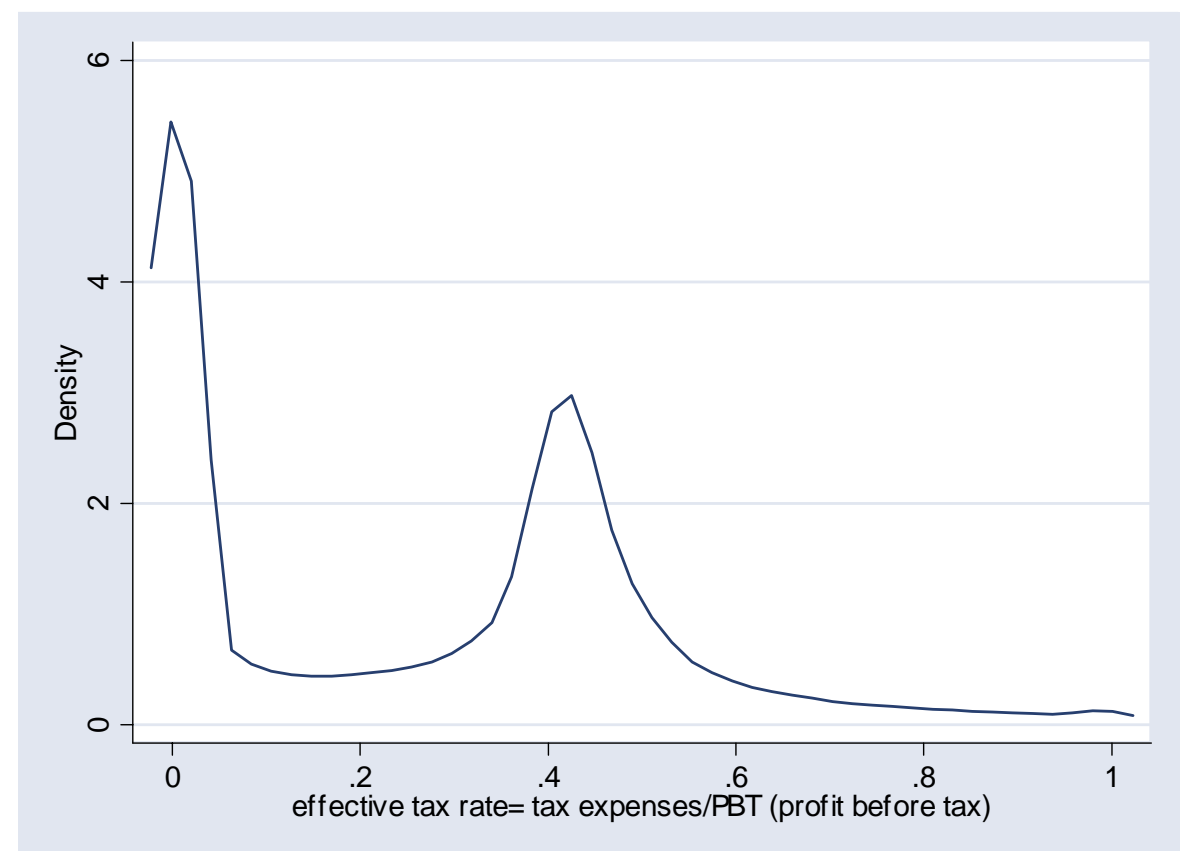




\section{References}

Balsam, S., J. Krishnan, and J.S. Yang, (2003), Auditor Industry Specialization and Earnings Quality, in: Auditing: A Journal of Practice \& Theory, vol. 22, No. 2, pp. 71-97.

Becker, C.L., M.L. Defond, J. Jiambalvo, and K.R. Subramanyam, (1998), The Effect of Audit Quality on Earnings Management, in: Contemporary Accounting Research, Vol. 15, No. 1, pp. 1-24.

Buijink, W., Janssen, B. and Schols, Y. (2000), Effective Tax Rates for Medium-Sized Companies in the EU-countries, Research project for the Dutch Ministry of Finance, The Netherlands, pp. 53.

Buijink, W., Janssen, B. and Schols, Y. (2002), 'Evidence of the Effect of domicile on Corporate Average Effective Tax Rates in the European Union', Journal of International Accounting, Auditing \& Taxation, 11, pp. 115-130.

Callihan, D. (1994), 'Corporate Effective Tax Rates: A Synthesis of the Literature', Journal of Accounting Literature, 13, pp. 1-43.

Collins, J.H. and Shackelford, D.A. (2002), Do U.S. Multinationals Face Different Tax Burdens than do Other Companies?, paper prepared for the NBER conference on Tax Policy and the Economy in Washington, D.C. on October 8.

De Beelde, I., (1997), An Exploratory Investigation of Industry Specialization of Large Audit Firms, in: The International Journal of Accounting, Vol. 32, No. 3, pp. 337-355.

Devereux, M.P., Griffith R., Klemm, A. (2002), 'Corporate income tax reforms and international tax competition', Economic Policy, 35, pp. 451-495.

Dunbar, A.E., and J.D. Philips, (2001), The Outsourcing of Corporate Tax Function Activities, in: The Journal of the American Taxation Association, Vol. 23, No. 2, pp. 35-49.

Gupta, S. and Newberry, K. (1997), 'Determinants of the variability in Corporate Effective 
Tax Rates: Evidence from Longitudinal Data', Journal of Accounting and Public Policy, 16, pp. 1-34.

Huizinga, H. and Nicodème G. (2003), Foreign Ownership and Corporate Income Taxation: An Empirical Evaluation, CEPR Discussion Paper nr. 3952, London, pp. 43.

KPMG, (2003), Corporate tax rate survey.

Krishnan, G.V., (2003), Does Big 6 Auditor Industry Expertise Constrain Earnings Management?, in: Accounting Horizons, Vol. 17, Supplement, pp. 1-16.

Lennox, C.S., 1999, Audit Quality and Auditor Size: An Evaluation of Reputation and Deep Pockets Hypotheses, in: Journal of Business Finance \& Accounting, vol. 26, No. 7 \& 8, pp. 779-805.

Mills, L.F., M.M. Erickson, and E.L. Maydew, (1998), Investments in Tax Planning, in: The Journal of the American Taxation Association, Vol. 20, No. 1, pp. 1-20.

Mills, L.F. and K.J. Newberry, (2001), The Influence of Tax and Nontax Costs on Book-Tax Reporting Differences: Public and Private Firms, in: The Journal of the American Taxation Association, Vol. 23, No. 1, pp. 1-19.

Nicodème, G. (2001), Computing Effective Corporate Tax Rates: Comparisons and results, DG ECOFIN economic paper nr. 153, Brussels, pp 50.

Roberts, C., P. Weetman and P. Gordon, (2002), International financial accounting: $a$ comparative approach, Financial Times/Prentice Hall, Second edition, pp. 113.

Shackelford, D.A., and T. Shevlin, (2001), Empirical tax research in accounting, in: Journal of Accounting and Economics, Vol. 31, No. 1-3, pp. 321-387.

Vandenbussche, H., B. Janssen and K. Crabbé, (2005), Is there Regional Tax Competition in Belgium?, De Economist, forthcoming. 
Vander Bauwhede, H., M. Willekens, (2004), Evidence on (the Lack of) Audit-quality Differentiation in the Private Client Segment of the Belgian Audit Market, in: European Accounting Review, Vol. 13, No. 3, pp. 501-522.

Van Kerchove, W., Heirewegh, G. (2003), Praktisch vennootschapsbelasting, aanslagjaar 2003, Uitgeverij de Boeck, Antwerpen, pp. 363.

Willekens M. and C. Achmadi (2003),"Pricing and Supplier concentration in the private Client segment of the audit market: market power or competition ?", The international Journal of Accounting, 38, pp. 431-455.

Zimmerman, J. (1983), 'Taxes and Firm Size', Journal of Accounting and Economics, 5, nr. 2, pp. 119-149. 